\title{
FIGHT AGAINST CORRUPTION IN THE SPHERE OF PUBLIC HEALTH CARE: MEANS OF INFORMATION PROVISION FOR CRIMES INVESTIGATION
}

\begin{abstract}
Pavliuk N. .
The paper considers the questions of applying scientific and technical means of information provision for corruption crimes investigation, researches on corruption directions of activity and corresponding risks of corruption manifestation in the sphere of public health of Ukraine, as well as the possibility to use these data for filling of a database of the automated information system "Corruption counteraction» are considered. The offered system is a means of information provision for the formation of proofs in the investigation of a corruption oriented crimes and will give the chance to the subjects authorized on carrying out pre-trial inquiry, to get uninterrupted access to the systematized information, to take potentially useful data, to receive offers of optimal decisions, sequences of actions and result in the convenient form for the decision of tactical problems. On the basis of studying of activity directions in public health care sphere of Ukraine there are presented the proposals concerning the list of corruption risks, the main from them are: imperfect mechanism of the organization and carrying out of the state purchases of medical preparations and equipment; impossibility of the automated control over procedure of purchases; avoidance of officials responsibility for decision-making; possibility of the companiesintermediaries to take part in purchases; imperfect systems of declaring on cost of medicines; absence of control over factual receipt of the goods and services, their quality, quantity, suitability terms; inconsistence of the treaty provisions to the offer of the auction winner; laying down discrimination conditions for the participation in the public sale; refusal of the customer to conclude the contract with auction winners; possibility of purchase conditions infringement; absence of a single register of patients which need treatment; absence of open competition choice of the heads of public health care institutions.

Keywords: corruption crimes, means of information provision of investigation, information systems, automated computer program, corruption risks.
\end{abstract}

В. О. Яремчук, асистент кафедри криміналістики Національного юридичного університету імені Ярослава Мудрого, кандидат юридичних наук

\section{УЧАСТЬ СПЕЦІАЛІСТА ПРИ ПЛАНУВАННІ РОЗСЛІДУВАННЯ ЗЛОЧИНУ}

Розглянуто особливості залучення спеціаліста до планування розслідування злочину. Запропоновано форми допомоги спеціаліста при організації проведення слідчих (розшукових) дій. Визначено форми допомоги спеціаліста при плануванні окремих негласних слідчих (розшукових) дій.

Ключові слова: організачія та планування розслідування злочину, спеціаліст, спеціальні знання, слідчі (розшукові) дії, негласні слідчі (розшукові) dii. 
Розслідування кримінальних правопорушень досить часто супроводжується залученням обізнаних осіб (спеціалістів, експертів), які суттєво допомагають слідчому встановлювати й досліджувати важливі об'єкти та обставини, що мають значення для розкриття злочину. Наразі істотну допомогу слідчому надають різноманітні спеціалісти, які залучаються 3 державних і недержавних установ, підприємств, організацій. Допомога спеціаліста суттєво впливає на якість і результат проведення окремих слідчих (розшукових) дій, негласних слідчих (розшукових) дій і на весь процес розслідування кримінальних правопорушень. Однак на сьогодні в криміналістичній літературі детально не розкриті форми допомоги спеціаліста при плануванні проведення слідчих (розшукових) дій і негласних слідчих (розшукових) дій.

На важливість використання спеціальних знань при плануванні розслідування звертали увагу такі вчені, як Б. Ю. Бистрицький, Г. Гросс, В. І. Дячук, М. Г. Куп'янський, А. М. Лазебний, Б. В. Романюк, М. П. Хилобок, В. Ю. Шепітько та ін. ${ }^{1}$

Так, засновник науки криміналістики Г. Гросс у п’ятій главі своєї праці вказує, що слід за можливістю розширити кількість звернень до обізнаних осіб і залучати їх до розслідування навіть тоді, коли в слідчого на перший погляд не виникає сумнівів. Автор пише про слідчих, що працювали тривалий час у поліції, та крім лікарів, мікроскопістів, мінерологів і зброярів не зверталися за допомогою, приміром, до ремісників чи професорів, які б надали їм цінні консультації. Г. Гросс наводить приклад зі своєї практики, коли, викликавши майстра зі зброї, він запитав у нього, що той може повідомити про вилучений ніж. Консультація спеціаліста про те, що такі ножі виробляються тільки в північній Богемії, допомогла під час пошуку вбивці² .

1 Див.: Бистрицький Б. Ю. Розслідування грабежів, учинених неповнолітніми: автореф. дис. ... канд. юрид. наук: спец. 12.00.09 «Кримінальний процес та криміналістика; судова експертиза; оперативно-розшукова діяльність». Київ, 2016. 20 с.; Гросс Г. Руководство для судебных следователей как система криминалистики/пер. с нем. Л. Дудкин, Б. Зиллер. Изд. 4-е, доп. СПб.: Тип. М. Меркушева, 1908. 1040 с.; Дячук В. I. Використання спеціальних знань при розслідуванні дорожньо-транспортних пригод: автореф. дис. ... канд. юрид. наук: спец. 12.00 .09 «Кримінальний процес та криміналістика, судова експертиза; оперативно-розшукова діяльність». Київ, 2010. 19 с.; Куn'янський М. Г. Розслідування серійних сексуально-садистських убивств (організаційно-тактичні засади) : автореф. дис. ... канд. юрид. наук: спец. 12.00.09 «Кримінальний процес та криміналістика; судова експертиза; оперативно-розшукова діяльність». 2016. 20 с.; Лазебний A. М. Використання спеціальних знань при розслідуванні кримінальних правопорушень проти громадського порядку: автореф. дис. ... канд. юрид. наук: спец. 12.00 .09 «Кримінальний процес та криміналістика; судова експертиза; оперативно-розшукова діяльність». Ірпінь, 2016. 16 с.; Романюк Б. В. Участь спеціаліста на стадії досудового слідства: навч. посібник. Київ: АванпостПрим, 2010. 304 с.; Хилобок М. П. Криминалистическая экспертиза. Раздел 2: Участие специалиста-криминалиста в следственных действиях/под общ. ред. И. М. Лузгина. М., 1966. Вып. 1. С. 126-152; Шепитько В. Проблемы использования специальных знаний в уголовном судопроизводстве. Вибрані твори. Харків: Апостіль. 2010. С. 491.

2 Гросс Г. Зазнач. твір. С. 190-191. 
У криміналістичній літературі проблемам участі спеціаліста при плануванні слідчих (розшукових) дій нині приділено недостатньо уваги. Так, під плануванням досудового розслідування розуміють визначення шляхів розкриття злочинів, окреслення обставин, що слід з'ясувати, а також установлення найдоцільніших строків проведення необхідних слідчих (розшукових) дій, інших процесуальних дій і організаційно-технічних заходів ${ }^{1}$. Завданнями планування розслідування постають: визначення оптимальних шляхів розслідування; об'єктивність, повнота, а також усебічність розслідування; своєчасність у застосуванні науково-технічних засобів і тактичних прийомів; поєднання слідчих (розшукових) дій, організаційно-технічних заходів при розслідуванні; сприяння економічному використанню процесуальних засобів ${ }^{2}$. Тому вагомого значення для успішного планування розслідування набуває участь у ньому спеціаліста.

Слід зазначити, що діяльність із підготовки до проведення слідчої (розшукової) дії складається з комплексу операцій, які послідовно реалізуються: по-перше, побудова мисленєвої моделі ситуації, яка склалася, та прийняття рішення щодо проведення слідчої (розшукової) дії; по-друге, визначення мети, завдань і побудова плану проведення певної дії, розроблення й реалізація програми організаційного, інформаційного, кадрового, технічного, оперативного та іншого забезпечення ${ }^{3}$. Участь спеціаліста при плануванні слідчої (розшукової) дії - це можливість використання його допомоги на всіх етапах їі організації. При залученні спеціаліста до планування слідчої (розшукової) дії слідчий визначається: 1) із формою допомоги спеціаліста, що буде надаватися при організації проведення слідчої (розшукової) дії; 2) із якої установи, підприємства, організації тощо залучити спеціаліста або ж спеціаліста, який не працює в таких установах (скульптор, художник, мисливець тощо); 3) із кількістю спеціалістів за необхідності отримання консультації з різних галузей спеціальних знань залежно від потрібної форми їх допомоги.

На важливості використання допомоги спеціалістів при підготовці й проведенні окремих слідчих (розшукових) дій наголошується також і в дисертаційних дослідженнях. Так, за результатами анкетування 105 слідчих органів досудового розслідування Міністерства внутрішніх справ України, проведеного М. Г. Куп'янським, при розслідуванні серійних сексуальносадистських убивств запрошують різноманітних спеціалістів, зокрема психологів, патопсихологів, психіатрів, криміналістів, сексологів, судово-медичних експертів, судових біологів, експертів-криміналістів, грунтознавців. Слідчі під час розслідування залучали спеціалістів при проведенні слідчих (розшукових) дій $(57,1$ \%); зверталися до спеціалістів із метою розроблення психологічних профілів (портретів) (46,7%); запрошували спеціалістів для

1 Криміналістика: підручник/за ред. В. Ю. Шепітька. 5-те вид., переробл. та допов. Київ: Ін Юре, 2016. С. 240-242.

2 Шепітько В. Ю. Вступ до навчального курсу «Криміналістика»: лекція. Київ: Ін Юре, 2016. С. 124.

3 Следственные действия: психология, тактика, технология: учеб. пособие/ М. И. Еникеев и др. М.: Проспект, 2008. С. 10. 
отримання ДНК-аналізу або проведення геномної експертизи (42,9 \%); зверталися до спеціалістів для отримання консультацій $(39 \%)^{1}$.

Погляди науковців на проблему визначення форм допомоги спеціаліста при плануванні розслідування у вітчизняній криміналістиці різняться. Про технічну форму допомоги спеціаліста пише А. М. Лазебний, і вказує, що слід доповнити ст. 223 Кримінального процесуального кодексу України (КПК України) нормою, де необхідно передбачити обов'язкову участь спеціалістів під час слідчих (розшукових) дій із застосуванням науково-технічних засобів щодо виявлення, фіксації та вилучення слідів кримінальних правопорушень ${ }^{2}$. Як відомо, у ч. 1 ст. 71 КПК України передбачено надання спеціалістом консультацій під час проведення досудового розслідування й судового розгляду з питань, що потребують використання спеціальних знань і навичок. На думку В. Г. Гончаренка та І. В. Гори, спеціаліст як консультант $\epsilon$ фігурою в судочинстві відносно новою й цей аспект його діяльності задіяний далеко не повною мірою. Науковці детально розкривають консультаційну форму допомоги спеціаліста сторонам кримінального провадження при призначенні експертизи, а саме консультації щодо доцільності іiї проведення, визначення роду й виду експертизи, визначення переліку документів, що слід надати експерту로. I. В. Курилін пише про консультативну форму допомоги при розслідуванні кримінальних правопорушень, які посягають на права інтелектуальної власності. У цих випадках спеціалісти надають допомогу у формі консультацій, порад, рекомендацій, довідкової інформації ${ }^{4}$ Слід звернути увагу на позицію Б. В. Романюка, який виділяє форми допомоги спеціаліста, зокрема, при плануванні проведення слідчої (розшукової) дії - методична допомога спеціаліста, консультація слідчого щодо правильних і науково обгрунтованих методик стосовно способів організації й проведення слідчих (розшукових) дій. Дискусійною вважаємо думку автора, що консультативна допомога спеціаліста перед проведенням слідчої (розшукової) дії це поза процесуальне самостійне здобуття слідчим необхідних знань і підвищення його професійного рівня. На думку науковця, не можна чітко розмежовувати форми допомоги спеціаліста, тому що вони можуть надаватися одночасно ляти мету запрошення спеціаліста при плануванні розслідування.

Іншу точку зору має В. В. Семенов, який виокремлює довідкову форму допомоги спеціаліста й консультативну ${ }^{6}$. Дещо по-іншому на цю проблему

${ }^{1}$ Куп'янський М. Г. Зазнач. твір. С. 14-16.

2 Лазебний А. М. Зазнач. твір. С. 5

3 Експертизи у судочинстві України: наук.-практ. посібник/за заг. ред. В. Г. Гончаренка та І. В. Гори. Київ: Юрінком Інтер, 2015. С. 37.

${ }^{4}$ Курилін I. Р. Використання спеціальних знань при розслідуванні злочинів, які посягають на права інтелектуальної власності: автореф дис. ... канд. юрид. наук: спец. 12.00.09 «Кримінальний процес та криміналістика; судова експертиза». Київ, 2007. C. 7.

5 Романюк Б. В. Зазнач. твір. С. 104-105.

6 Семенов В. В. Спеціальні знання в розслідуванні злочинів (зміст, організація використання): автореф. дис. ... канд. юрид. наук: спец. 12.00.09 «Кримінальний процес та криміналістика; судова експертиза». Київ, 2006. С. 15. 
дивиться В. Я. Марчак і розрізняє запрошення спеціаліста-психолога, який бере участь у проведенні слідчих (розшукових) дій, і консультанта-психолога, який надає усні консультації довідкового характеру перед проведенням слідчих (розшукових) дій. Автор пропонує на законодавчому рівні визнати джерелом доказів консультацію психолога ${ }^{1}$. Так, А. М. Лазебний виділяє «непроцесуальну» форму діяльності спеціаліста, тобто отримання слідчим від нього криміналістично значущої інформації, яка б дозволила правильно визначити порядок, час, місце процесуальної дії, коло учасників, науковотехнічні засоби, методи та обрати тактичні прийоми тощоㅇ․

Слід виокремити також аналітичну форму допомоги спеціаліста при плануванні розслідування - це його участь у складанні плану розслідування. Такий документ є організуючим чинником у діяльності з розслідування кримінальних правопорушень ${ }^{3}$. Так, А. А. Макар'їн також зазначає про аналітичну форму допомоги, уважаючи, що під час слідчих (розшукових) дій спеціалісти беруть участь у висуненні й перевірці версій. Науковець пропонує алгоритми організації участі спеціалістів у плануванні слідчих (розшукових) дій ${ }^{4}$.

Можна виділити праці вчених, які характеризують форми допомоги спеціаліста не в цілому при плануванні розслідування окремих видів кримінальних правопорушень, а під час планування окремої слідчої (розшукової) дії. Як зазначає М. П. Хилобок, при плануванні слідчого експерименту спеціаліст допомагає слідчому: а) в обранні умов проведення експерименту. Так, вивчивши протоколи огляду місця події, допиту тощо, спеціаліст надає поради слідчому стосовно істотних умов для проведення слідчого експерименту, а також щодо підбору інструментів і матеріалів; б) спеціаліст може порадити провести досліди декілька разів або запросити до участі в слідчому експерименті спеціалістів іншого фаху; в) беручи участь у реконструкції перед проведенням слідчого експерименту, спеціаліст може допомогти слідчому в обранні аналогів знарядь злочину; г) спеціаліст готує всі небхідні для фіксації дослідів науково-технічні засоби 5 . Свої погляди на форми допомоги спеціаліста при плануванні слідчого експерименту під час розслідування дорожньо-транспортних подій висловлює в науковому дослідженні В. І. Дячук. Він пише про використання слідчим допомоги спеціаліста-автотехніка під час проведення таких дій: 1) при визначенні мети та розробленні плану проведення слідчого експерименту; 2) при підготовці умов відтворення з максимальним наближенням до реальної обстановки на

${ }^{1}$ Марчак В. Я. Використання спеціальних психологічних знань у досудовому слідстві: автореф. дис. ... канд. юрид. наук: спец. 12.00.09 «Кримінальний процес та криміналістика; судова експертиза». Київ, 2003. С. 10-11.

2 Лазебний А. М. Зазнач. твір. С. 10.

${ }^{3}$ Malevski H., Shepitko V. Textbook of criminalistics. Vol. I: General Theory. Kharkiv: Apostille Publishing House LLC. P. 218-226.

${ }_{4}$ Макарьин A. A. Оптимизация участия специалиста при производстве расследования по уголовному делу : автореф. дис. ... канд. юрид. наук: спец. 12.00.09 «Уголовный процесс; криминалистика и судебная экспертиза». СПб., 2006. С. 8.

${ }^{5}$ Хилобок М. П. Зазнач. твір. С. 140-141. 
всіх стадіях дорожньо-транспортної події; 3) при підготовці транспортних засобів і учасників до слідчого експерименту; 4) при розробленні окремих завдань відтворення обставин дорожньо-транспортної події тощо ${ }^{1}$.

Допомога спеціаліста може полягати у встановленні доцільності проведення певної слідчої (розшукової) дії або негласної слідчої (розшукової) дії. Так, у ч. 2 ст. 223 КПК України вказано, що підставами для проведення слідчої (розшукової) дії $є$ наявність достатніх відомостей, що вказують на можливість досягнення ії мети. Тобто спеціаліст, якого залучено при плануванні проведення слідчої (розшукової) дії, може детально роз'яснити слідчому, за яких саме умов може бути досягнута мета ії̈ проведення. Наведемо приклад. В одному із сіл Харківської області місцевий житель пошкодив об'єкт магістрального газопроводу шляхом приварювання металевої труби. Коли слідчий звернувся до спеціаліста за консультацією перед проведенням слідчого експерименту, останній указав, що без спеціальних знань неможливо у такий спосіб приєднатися до газотрубопроводу. Спеціаліст надав консультації слідчому щодо організації проведення слідчого експерименту з метою перевірки спеціальних і професійних навичок особи, надавши організаційну й технічну допомогу. Під час проведеної слідчої дії підозрюваний підтвердив свої показання та продемонстрував, яким чином він здійснював газозварювальні роботи.

Анкетування слідчих МВС України та СБ України, проведене нами, засвідчило, що допомога спеціалістів слідчому під час планування розслідування полягає: а) у своєчасному застосуванні різноманітних науково-технічних засобів, зокрема, використанні пересувної криміналістичної лабораторії - 59,6 \%; б) у висуненні слідчих версій - 22,2 \%; в) в аналізі окремих матеріалів кримінального провадження $-21,3 \%$; г) в обранні часу й термінів проведення слідчих (розшукових) дій, негласних слідчих (розшукових) дій та інших заходів - 20,4 \%; д) у складанні плану розслідування - 12,2 \%; є) в іншому $-3,9 \%{ }^{2}$.

Ураховуючи викладене, слід виділити форми допомоги спеціаліста при плануванні слідчої (розшукової) дії: 1) консультативну (під час планування пред'явлення для впізнання - спеціаліст допомагає підібрати об'єкти, що будуть пред'являтися особі, а також консультує слідчого стосовно окремих умов, які впливали на сприйняття об'єкта особою. Так, перед проведенням допиту спеціаліст надає консультації щодо місця, часу та тривалості проведення допиту малолітньої чи неповнолітньої особи); 2) аналітичну форму допомоги (при висуненні слідчим версій, в оцінюванні наявних доказів і матеріалів кримінального провадження і на їх підставі сприяння в організації необхідної слідчої (розшукової) дії, негласної слідчої (розшукової) дії тощо); 3) організаційну (при плануванні обшуку - допомога в обранні сприятливого часу його проведення); 4) технічну форму допомоги (при обранні приладів, які слід використати при проведенні слідчої (розшукової) дії),

\footnotetext{
${ }^{1}$ Дячук В. I. Зазнач. твір. С. 9.

2 Дані проведеного нами анкетування 230 слідчих Міністерства внутрішніх справ України та Служби безпеки України у 2013 р.
} 
допомога в установленні відеозв'язку при проведенні допиту або пред'явлення для впізнання в режимі відеоконференції відповідно до ст. 232 КПК України; 5) довідкову (роз'яснення спеціалістом довідкових даних при обранні часу й термінів проведення слідчої (розшукової) дії, негласної слідчої (розшукової) дії тощо); 6) підготовчу допомогу - спеціаліст допомагає слідчому визначитися із кількістю статистів при проведенні слідчого експерименту або пред’явлення для впізнання тощо.

Для слідчого важливим є обрання експертної установи або підприємства чи організації, з якої буде залучатися спеціаліст. У певних випадках при організації проведення окремої слідчої (розшукової) дії слідчому необхідно отримати допомогу від декількох спеціалістів. Це пов'язано із видом учиненого кримінального правопорушення, потребою одночасного використання різних видів спеціальних знань, складністю проведення самої слідчої (розшукової) дії.

Новим напрямом використання допомоги спеціаліста є його залучення при плануванні негласних слідчих (розшукових) дій. Відповідно до п. 3.1 Інструкції про організацію проведення негласних слідчих (розшукових) дій та використання їх результатів у кримінальному провадженні слідчий може здійснювати негласні слідчі (розшукові) дії самостійно, спільно з уповноваженими оперативними підрозділами, залучати до їх проведення інших осіб, а також доручати їх проведення уповноваженим оперативним підрозділам ${ }^{1}$. Отже, можливим є залучення відповідних спеціалістів при проведенні негласних слідчих (розшукових) дій.

Таким чином, науковці виділяють такі напрями використання слідчими і спеціалістами спеціальних знань у зв'язку з проведенням негласних слідчих (розшукових) дій: для їх підготовки, безпосередньо під час їх здійснення, для фіксації, оформлення одержаних результатів і їх збереження, проведення дослідження отриманих матеріалів. На підготовчій стадії використання спеціальних знань пов'язано із обранням доцільних умов проведення негласних слідчих (розшукових) дій, підготовкою й виготовленням технічних чи імітаційних засобів, визначенням кола учасників і їх інструктажем. Консультативна допомога спеціаліста при плануванні негласних слідчих (розшукових) дій полягає в наданні роз'яснень, порад, повідомлення відомостей довідкового характеру, що сприяють належній підготовці до проведення негласних слідчих (розшукових) дій. Методична допомога спеціаліста полягає, на думку науковців, у відпрацюванні прийомів здійснення окремих дій для отримання інформації. Технічна допомога спеціаліста передбачає його участь у вимірюванні, фотографуванні, складанні планів, схем, графічних зображень. Цей вид допомоги надається слідчому та іншим осо-

1 Про затвердження Інструкції про організацію проведення негласних слідчих (розшукових) дій та використання їх результатів у кримінальному провадженні: наказ Ген. прокуратури України, МВС України, СБ України, Адміністрації Держ. прикордон. служби України, М-ва фінансів України, М-ва юстиції України від 16.11.2012 № 114/1042/516/1199/936/1687/5. URL: http://zakon3.rada.gov.ua/laws/show/v011490012 (дата звернення 11.06.2017). 
бам, залученим до підготовки й проведення негласних слідчих (розшукових) дій $^{1}$. Тобто форми допомоги спеціаліста при його участі в плануванні та організації негласної слідчої (розшукової) дії схожі із формами його допомоги при організації й плануванні слідчої (розшукової) дії. Однак специфіка проведення певної негласної слідчої (розшукової) дії зумовлює обрання форми допомоги спеціаліста при ії плануванні. Так, при плануванні таких негласних слідчих (розшукових) дій, як аудіо-, відеоконтроль особи (ст. 260 КПК України), зняття інформації з транспортних телекомунікаційних мереж (ст. 263 КПК України), зняття інформації з електронних інформаційних систем (ст. 264 КПК України), аудіо-, відеоконтроль місця (ст. 270 КПК України), установлення місцезнаходження радіоелектронного засобу (ст. 268 КПК України), спостереження за особою, річчю або місцем (ст. 269 КПК України), спеціалістом може надаватися в більшості випадків організаційна й технічна допомога. При плануванні проведення огляду та виїмки кореспонденції (ст. 262 КПК України), контролю за вчиненням злочину (ст. 271 КПК України) спеціалістом може надаватися консультативна, аналітична, підготовча, довідкова допомога.

3 огляду на викладене, при залученні спеціаліста при плануванні слідчої (розшукової) дії слідчий визначається: із фахом потрібного спеціаліста, а також із якої установи його буде залучено; із формою допомоги спеціаліста, що буде ним надана при організації проведення слідчої (розшукової) або негласної слідчої (розшукової) дії. Можна виділити консультативну, аналітичну, організаційну, технічну, довідкову, підготовчу форми допомоги спеціаліста при його участі в плануванні проведення окремої слідчої (розшукової) чи негласної слідчої (розшукової) дії. Форми допомоги спеціаліста залежать від виду вчиненого кримінального правопорушення. Слід також ураховувати специфіку в організації й тактиці проведення певної слідчої (розшукової) чи негласної слідчої (розшукової) дії. В окремих випадках слідчому доцільно отримати допомогу від декількох спеціалістів.

\section{УЧАСТИЕ СПЕЦИАЛИСТА ПРИ ПЛАНИРОВАНИИ РАССЛЕДОВАНИЯ ПРЕСТУПЛЕНИЯ}

\section{Яремчук В. $О$.}

Рассмотрены особенности привлечения специалиста к планированию расследования преступления. Предложены формы помощи специиалиста при организации проведения следственных (розыскных) действий. Определены формы помощи специалиста при планировании отдельных негласных следственных (розыскных) действий.

Ключевые слова: организация и планирование расследования преступления, специилист, специальные знания, следственные (розыскные) действия, негласные следственные (розыскные) действия.

1 Негласні слідчі (розшукові) дії та використання результатів оперативно-розшукової діяльності у кримінальному провадженні: навч.-практ. посібник/С. С. Кудінов та ін. 2-ге вид., розшир. й допов. Харків: Оберіг, 2015. С. 17-18. 


\section{PARTICIPATION OF A SPECIALIST WHEN PLANNING INVESTIGATION OF A CRIME}

\section{Yaremchuk V.O.}

Investigation of criminal offences is often frequently accompanied by involvement of informed persons which help the investigator to establish and investigate the important circumstances. The essential help to the investigator is given by different specialists who are involved from state and private institutions, enterprises, organizations. However, today in the criminalistic literature the forms of the specialist help in details in planning of carrying out investigative (search) actions, covert investigative (search) actions are not revealed. The aim of the paper is determination of a specialist participation in planning crime investigation. When involving a specialist in planning investigative (search) action, an investigator clarifies himself: 1) with the form of the help of the expert which will be given when organizing of carrying out investigative (search) action; 2) with a speciality of the necessary specialist, and also from what institution, enterprise or organization one has to involve the specialist or the specialist who does not work in such institutions (sculptor, artist, hunter and others); 3) depending on a type of a criminal offence, on the need of simultaneous use of different kinds of special knowledge, on complexity of carrying out investigative (search) action itself or covert investigative (search) action whether it's necessary to receive the help of several specialists. It's possible to distinguish advisory, analytical, organizational, technical, reference, preparatory forms of the specialist help at his participation in planning of carrying out investigative (search) or covert investigative (search) action. Forms of the specialist help depend on a type of a criminal offence. It's necessary to take into account the specificity in carrying out certain investigative (search) or covert investigative (search) action. Sometimes it's expedient for an investigator to receive the help of several specialists when organizing carrying out such separate actions.

Keywords: organization and planning of crime investigation, specialist, special knowledge, investigative (search) actions, covert investigative (search) actions.

O. I. Резнікова, асистент кафедри кримінального процесу та оперативно-розшукової діяльності Національного юридичного університету імені Ярослава Мудрого, кандидат юридичних наук

\section{ЩОДО КРИМІНАЛІСТИЧНОГО РОЗУМІННЯ ЗЛОЧИНІВ КОРУПЦІЙНОЇ СПРЯМОВАНОСТІ}

Проаналізовано чинне кримінальне та антикорупційне законодавство України. Виявлено розбіжності стосовно правового регулювання настання кримінальної відповідальності за корупційні й пов'язані з корупцією злочини, окреслено иляхи їх усунення. Доведено необхідність застосування діяльнісного підходу щцодо криміналістичного розуміння злочинів корупційної спрямованості.

Ключові слова: корупція; злочини корупційної спрямованості; корупџійні злочини; злочини, пов'язані з корупџією; злочинна корупџійна діяльність. 